\title{
Article \\ Solar Power System Assessments Using ANN and Hybrid Boost Converter Based MPPT Algorithm
}

\author{
Imran Haseeb ${ }^{1}$, Ammar Armghan ${ }^{2} \mathbb{D}$, Wakeel Khan ${ }^{3}$, Fayadh Alenezi ${ }^{2} \mathbb{D}$, Norah Alnaim ${ }^{4} \mathbb{D}$, Farman $^{\text {Ali }}{ }^{1, *(\mathbb{D})}$, \\ Fazal Muhammad ${ }^{5}$, Fahad R. Albogamy ${ }^{6, *}$ and Nasim Ullah ${ }^{7}$ (D)
}

Citation: Haseeb, I.; Armghan, A.; Khan, W.; Alenezi, F.; Alnaim, N.; Ali, F.; Muhammad, F.; Albogamy, F.R.; Ullah, N. Solar Power System Assessments Using ANN and Hybrid Boost Converter Based MPPT Algorithm. Appl. Sci. 2021, 11, 11332. https://doi.org/10.3390/app112311332

\section{Academic Editors: Luis}

Hernández-Callejo, Maria del

Carmen Alonso García and Sara Gallardo Saavedra

Received: 5 October 2021

Accepted: 26 November 2021

Published: 30 November 2021

Publisher's Note: MDPI stays neutral with regard to jurisdictional claims in published maps and institutional affiliations.

Copyright: (c) 2021 by the authors. Licensee MDPI, Basel, Switzerland. This article is an open access article distributed under the terms and conditions of the Creative Commons Attribution (CC BY) license (https:// creativecommons.org/licenses/by/ $4.0 /)$.
1 Department of Electrical Engineering, Qurtuba University of Science and IT, Dera Ismail Khan 29050, Pakistan; imranhaseeb@qurtuba.edu.pk

2 Department of Electrical Engineering, College of Engineering, Jouf University, Sakaka 72388, Saudi Arabia; aarmghan@ju.edu.sa (A.A.); fshenezi@ju.edu.sa (F.A.)

3 Department of Electrical Engineering, Foundation University Islamabad, Islamabad 44000, Pakistan; wakeel.khan@fui.edu.pk

4 Department of Computer Science, College of Sciences and Humanities in Jubail, Imam Abdulrahman bin Faisal University, Dammam 31441, Saudi Arabia; Nmalnaim@iau.edu.sa

5 Department of Electrical Engineering, University of Engineering Technology, Mardan 23200, Pakistan; fazal.muhammad@uetmardan.edu.pk

6 Computer Sciences Program, Turabah University College, Taif University, P.O. Box 11099, Taif 21944, Saudi Arabia

7 Department of Electrical Engineering, College of Engineering TAIF University KSA, Taif 21944, Saudi Arabia; nasimullah@tu.edu.sa

* Correspondence: drfarmanali.optics@qurtuba.edu.pk (F.A.); f.alhammdani@tu.edu.sa (F.R.A.)

Abstract: The load pressure on electrical power system is increased during last decade. The installation of new power generators (PGs) take huge time and cost. Therefore, to manage current power demands, the solar plants are considered a fruitful solution. However, critical caring and balance output power in solar plants are the highlighted issues. Which needs a proper procedure in order to minimize balance output power and caring issues in solar plants. This paper investigates artificial neural network (ANN) and hybrid boost converter (HBC) based MPPT for improving the output power of solar plants. The proposed model is analyzed in two steps, the offline step and the online step. Where the offline status is used for training various terms of ANNs in terms of structure and algorithm while in the online step, the online procedure is applied with optimum ANN for maximum power point tracking (MPPT) using traditional converter and hybrid converter in solar plants. Moreover, a detail analytical framework is studied for both proposed steps. The mathematical and simulation approaches show that the presented model efficiently regulate the output of solar plants. This technique is applicable for current installed solar plants which reduces the cost per generation.

Keywords: artificial neural network based MPPT; hybrid boost converter; renewable energies; solar power system

\section{Introduction}

The electrical energy plays a key role in the economic development of a country. From last decade, rapid increase in consumption of electricity and demand is recorded [1,2]. In order to fulfill power demands, installation of new power plants are time consumption and high expensive procedures [3]. The renewable energies, such as wind and solar, appear to be appropriate solutions to cover energy demand while reducing environmental pollution and toxic materials [4]. Furthermore, the renewable energy resources are followed by many countries, which comes from geothermal heat, tides, rain, wind, and sunlight. Major remote sites in each country of the globe utilizing renewable energy [5]. 
The renewable energy generated power depends on site selection and climate condition. Furthermore, there is a need of storage system power induced by renewable energy to insure the continuity of available power [6]. Various types of resources are existed in the entire globe, however, among of all these resources solar energy is considered economical, inexhaustible, and sustainable energy. Photovoltaic (PV) cells mostly use for bulk and small power and gradually increased day by day [7]. The output of PV depends on different factor such as temperature, weather conditions, module materials, and is used in different applications, i.e., light sources, battery charging, water pumping, space, satellite power system, remote islanded power system, etc. This work explores the applications of artificial neural network (ANN) and hybrid boost converter (HBC) for enhancing the efficiency for MPPT to increase the smoothness of solar power system. The deep learning based ANN mechanism has key features to optimize the input data and produce the purified desire outcomes. Furthermore, currently the ANN approach is widely used in several fields for the purpose of optimizing structure complexity and predict the expected outputs. For example, in [8] the ANN technique is utilized for predicting droughts, in [9] the ANN method is studied for accurately measure the wind speed and predict its results, in [10] the particular matter is discussed for the Ankara city through ANN and similarly, in the field of solar system the ANN is applied in [11] for forecasting the generation of solar system. Thus, in this proposed work the ANN mechanism is estimated for optimize the output of MPPT and HBC.

\subsection{Major Contribution}

The use of MPPT has increased the performance of solar power system and now the demand of solar plant installation is enhanced. The efficiency of the MPPT based solar system can be further improved applying ANN and HBC. Thus, this paper studies the contributions of ANN and HBC based MPPT in the solar system. The major contributions of this work are discussed as follows.

1. The outcomes of solar system are enhanced in this model using ANN and HBC based MPPT algorithm;

2. The mathematical model is elaborated in detail to show how the ANN and HBC based MPPT algorithm improve the quality of service of a solar power system;

3. The model is designed for simulation analysis and is compared among various procedures like Elman neural network (ENN), with install HBC and ANN mechanisms and without install $\mathrm{HBC}$ and ANN procedures in order to evaluate proposed model executions;

4. The proposed ANN model presents reliable outcomes in view of simple structure, fast training and robust performance. This effectiveness is further modified by applying HBC in the proposed model.

\subsection{Organization of Paper}

The rest of the paper is organized as follows: Section 2 explains the proposed framework; Section 3 investigates the analytical approach; Section 4 defines the result and discussions; similarly, Section 5 presents the conclusion.

\subsection{Related Work}

As it has been shown that solar energy is a cost effective solution for managing current electric load demands, a number of research work have been carried out so far, which are analyzed as follows:

In $[12,13]$, the authors have discussed the two artificial based mechanisms in term of variable and fixed step load. The theoretical and simulation analysis are investigation for MPPT controller, and simulation. In [14], authors have proposed the MPPT technique which is based on enhanced neural network (ENN). The proposed ENN based control have the ability to adjust the step size to track MPPT automatically and it can improve the dynamic and steady performance of PV panels. The proposed ENN technique can easily be implemented because of less constructed data. In [15], authors have proposed a MPPT 
converter using online learning neural network (OLNN) and perturbation and observation technique. The proposed work can improve the fast tracking of the solar panels when the radiation is changing constantly. The simulation results show improved output when the radiation is changing rapidly. In [16], authors have investigated an optimal power operating point (OPOP) using photovoltaic and thermal neural network (PV/TNN). The NN has been used to calculate the OPOP. The OPOP computes the optimum flow rate of PV/T for maximum electrical and thermal power. The results show that this technique can hold fast and accurate PV/T flow rate control. In [17], authors have presented the super twisting sliding mode MPPT controller (ST-SMC) with ANN. The robust sliding mode controller is used against disturbance and parametric variations while the ANN controls the peak power voltage for the efficiency of MPPT. The simulation results show the improved performance in terms of dynamic response and robustness. In [18], authors have suggested the two fast and digital MPPT techniques for fast changing environment. They approximate the MPP locus by using piecewise line segment or cubic equation. The MPP locus parameters are found with the help of NN based program. The results show that the proposed research required less computation requirement, high static, and dynamic tracking and fast speed. In [19], authors have proposed the different intelligence technique, i.e., neural network (NN), fuzzy logic (FL), genetic algorithm (GA), and neuro-fuzzy and their possible implementation into a field programmable gate array (FPGA). The authors have developed intelligent MPP controller using simulink/MATLAB and then different step to design and implement the controller into FPGA. The best controller among all these is tested in real time using FPGA Virtex 5. The comparative study of all controllers describe that the effectiveness of developed intelligence technique in term of accuracy, quick response, power consumption, flexibility, and simplicity. In [20], authors have presented the two techniques ANN and Fuzzy logic controller (FLC) for MPPT of PV cell. They investigate the proposed work using MATLAB/Simulink. The results show that the efficiency and response under variable irradiation conditions are satisfactory. In [21], authors have investigated the new combined method that is established by a three point comparing method and an ANN based PV model method. During the fast variations of solar irradiance, the exact MPP is searched by three point comparison and ANN methods. The results show that the proposed method search the exact and fast MPP under different irradiance condition with feedback voltage and current. In [22], authors have proposed the ANN method for the non-linear and time-varying output of PV panels. ANN is the suitable solution for non-linear outputs. The results also denote that the ANN algorithm have better MPPT characteristics as compared with the traditional perturbation and observation technique. In [23], authors have suggested the intelligent MPPT method for a standalone PV system using ANN and fuzzy logic controller (FLC). The ANN is used for different solar irradiance and temperature to find MPP voltage. FLC uses MPP voltage as a reference voltage to generate a control signal for the DC-DC converter. The results explain good performance of ANN-FLC as compared to traditional incremental conductance (IC). In [24], authors have investigated the method to achieve acceptable tracking time and less power oscillation by adjusting the changing step size of Flyback inverter. Solar irradiance is adopted as an input of ANN which is used to appropriate modulation step size. The simulation results show that for any solar irradiance ANN based Flyback inverter can find appropriate step size. In [25], authors have presented the MPPT using ANN, and the hysteresis current controlled inverter with fixed band and variation of load value is determined with output current total harmonic distraction (THD) is lower than $5 \%$. The results confirm that the efficiency of controller and flexibility of inverter is satisfactory. In [26], authors have proposed the MPPT of a grid connected $20 \mathrm{~kW}$ neuro-fuzzy network based PV system. The neuro-fuzzy system consists of fuzzy based classifier and three multilayered feed forwarded ANN. The inputs of ANN are irradiance and temperature, and, after the estimation process, output is the reference voltage. The reference voltage guarantees the optimal power transfer between PV generator and the main utility grid. The simulation results proved the best efficiency as compared to conventional single ANN and perturb 
and observe $(\mathrm{P} \& \mathrm{O})$ algorithm. The study in [27] reveals the performance of ANN based different algorithms, i.e., Levenberg-Marquardt (LM), Bayesian regularization (BR), and scaled conjugate gradient (SCG) algorithms are used in MPPT energy harvesting in solar photovoltaic system. The simulated results show that SCG algorithm reveal superior performance compared to LM and BR algorithms. However, the LM algorithm performs better in the correlation between input-output, dataset training, and error. A fuzzy logic, particle swarm optimization (PSO), and imperialist competitive algorithm are proposed in [28], where it is declared that the fuzzy logic is less complicated, faster, more accurate, and more stability then the other three algorithms. The authors have explored a hybrid shuffled frog leaping and pattern search (HSFL-PS) algorithm in [29] for optimizing ANNbased MPPT in a grid-tied PV system. The simulation results show that the performance of MPPT is improved in comparison with the conventional MPP methods. A novel ANNACO MPPT controller is developed by authors in [30] based on an ant colony optimization (ACO) algorithm which is useful to train the developed ANN. The ANN-ACO technique has improved the MPPT and reduced the drawbacks in conventional MPPT. The authors have also improved the power quality and distortion free signal to the grid. The simulation and experimental results show that ANN-ACO controller can track the MPP rapidly and robustness with a minimum steady-state oscillation than the conventional INC method. ANN based controller is used in [31] to control the converter fed by an autonomous photovoltaic generator (PVG) instead of classical MPPT algorithms such as perturb and observe $(\mathrm{P} \& \mathrm{O})$. The results present that the ANN based PVG provide low oscillation and better performance.

\section{Proposed ANN Based MPPT and Hybrid Boost Converter Model}

Figure 1 explains the HBC and ANN based MPPT presented model for minimizing the solar power system critical caring and balancing output power issues. The output of PV is attained by ANN based MPPT in order to improve the performance of solar power system. The neural network technique consist of major amount of interconnected processors called neurons. Each neuron includes a huge number of weighted links for transforming signals. Thus, it has potential to manage the difficult task of data processing and interpretation. In this proposed model, the feed forward back propagation ANN is installed which contains logsig purelin and purelin activation functions based hidden layers, as depicted in Figure 2. In case of offline step the ANN training is performed in terms of activation function structure and training algorithm. On the other side for online step the trained ANN based MPPT is applied to track the MPP. The output of PV array voltage derivation (dv) and power derivation (dp) is given to ANN based MPPT which depends on solar radiation and temperature conditions. Table 1 summarizes the basic principle of ANN based MPPT which output is corresponding normalized increasing or decreasing duty cycle $(+1,0,-1)$.

Table 1 explains the basic mechanism of ANN based MPPT controller.

Table 1. ANN based MPPT controller basic principle.

\begin{tabular}{cccl}
\hline $\mathbf{d v}$ & $\mathbf{d p}$ & $\mathbf{d p} / \mathbf{d v}$ & Duty Cycle \\
\hline-1 & -1 & -1 & $\mathrm{D}(\mathrm{n})=\mathrm{D}(\mathrm{n}-1)$ \\
\hline+1 & -1 & +1 & $\mathrm{D}(\mathrm{n})=\mathrm{D}(\mathrm{n}-1)$ \\
\hline-1 & +1 & +1 & $\mathrm{D}(\mathrm{n})=\mathrm{D}(\mathrm{n}-1)$ \\
\hline+1 & +1 & -1 & $\mathrm{D}(\mathrm{n})=\mathrm{D}(\mathrm{n}-1)$ \\
\hline
\end{tabular}



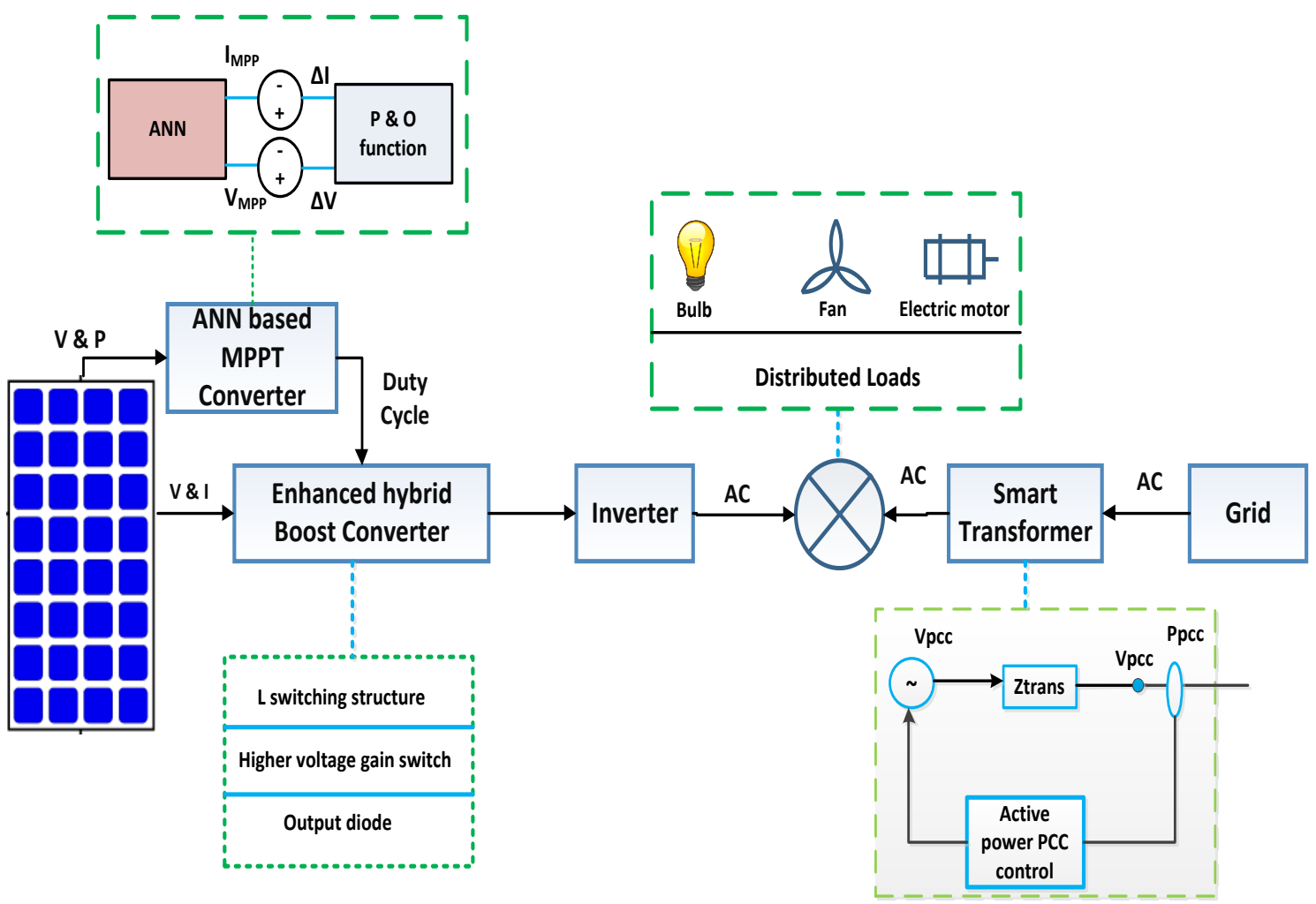

Figure 1. Proposed framework using ANN MPPT and enhanced hybrid boost converter.

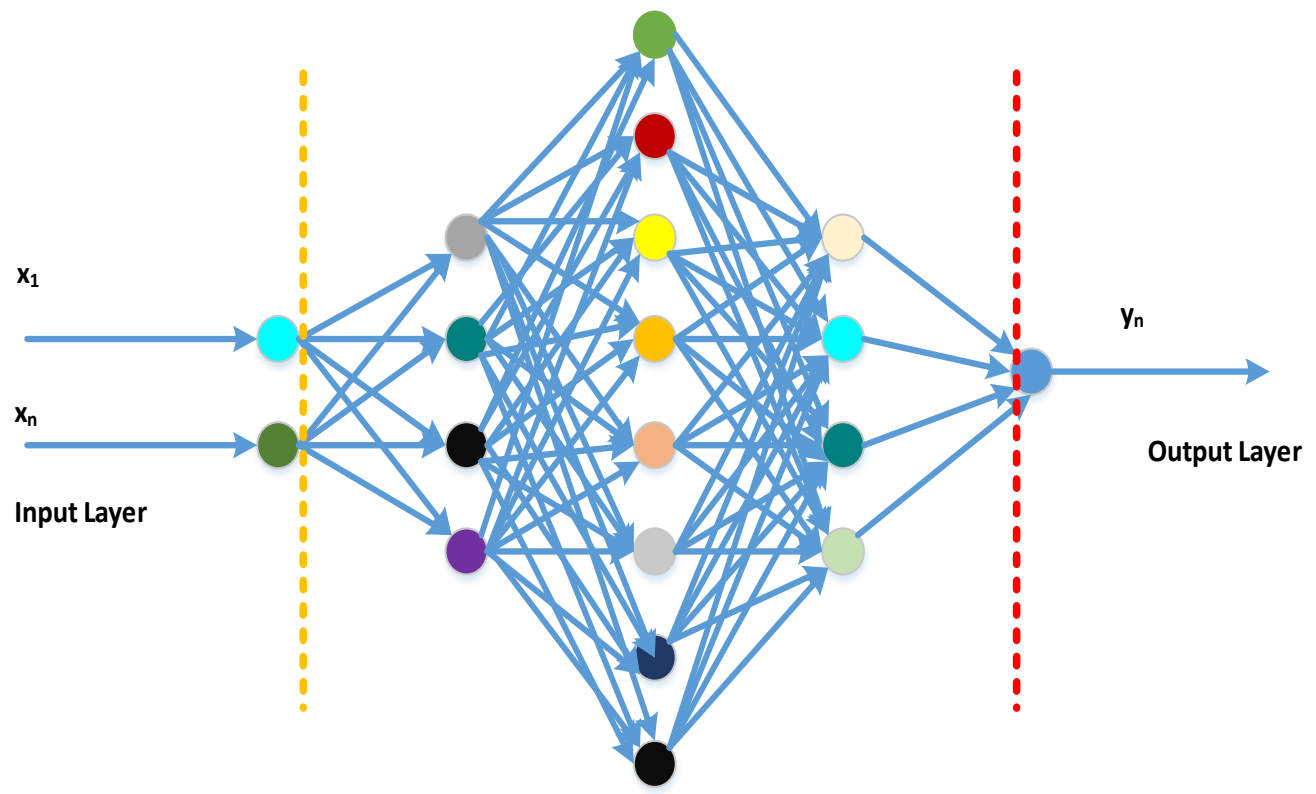

Hidden Layer

Figure 2. Internal structure of ANN based MPPT . 


\section{Analytical Approach}

\subsection{Analytical Model of PV Module}

The main background of the presented approach is discussed in Section 2. This section elaborates the mathematical mechanism for the modern MPPT based ANN system, considering the array of PVs at input side and utility grid at the receiving end. The description of used symbols are declared in Table 2. The circuitry of the PV cell contain diode for paralleling current as shown in Figure 3, which can be mathematically [32-34] defined as

$$
i_{\text {total }}=i_{s c}-i_{\text {diode }},
$$

where $i_{\text {diode }}$ is the diode current, $i_{s c}$ is the current through the parallel resistor. The $i_{\text {diode }}$ is further explained as

$$
i_{\text {diode }}=i_{o}\left(e^{\frac{e v_{d}}{\eta K T_{c}}}-1\right)
$$

So, the Equation (1) can be modified with Equation (2) the total current from PV cell is measured as

$$
i_{\text {total }}=i_{s c}-i_{o}\left(e^{\frac{e v_{d}}{\eta K T_{c}}}-1\right)
$$

Parallel resistance $R_{p}$ and series resistance $R_{s}$ is also considered for the dynamic behavior of PV cell, however, for the proposed PV cell simulation there is computational limitation if taking both series and parallel resistance. Therefore, parallel resistance is usually neglected in PV systems bibliography. For the proposed PV cell simulation series resistance is considered and the PV cell total current is mathematically written as $[35,36]$

$$
i_{\text {total }}=i_{s c}-i_{o}\left\{\exp \left(\frac{e\left(v+i_{\text {total }} R_{s}\right)}{\eta K T_{c}}\right)\right\}-1
$$

The PV system consist of $N$ numbers of branches in parallel and each parallel branch consist of $\mathrm{N}$ number of PV cells in series. So, the total current from PV module under constant weather condition is

$$
i_{s c}^{N}=i_{s c}^{N}\left[1-\exp \left(\frac{V^{m}-V_{o c}^{m}+R_{s}^{N} \cdot i^{N}}{N_{s} \cdot V_{T}^{c}}\right)\right]
$$

The module current depends on some different parameters of the cell. Each variable depends on different parameters of each cell. The module short circuit current depends on number of branches and short circuit of the cell $[37,38]$.

$$
i_{s c}^{M}=N_{p} \cdot i_{s c}^{c}
$$

The open circuit voltage of the module depends on the number of cells in series and the open circuit voltage of the cell.

$$
V_{o c}^{m}=N_{s} \times V_{o c}^{c}
$$

The thermal voltage of the semiconductor in the module depends on Boltzmann's constant, cell temperature and the charge of electron, i.e., $1.602 \times 10^{-19}$ [39].

$$
V_{T}^{c}=\frac{m K T_{c}}{e}
$$


The equivalent series resistant of the module depends on series resistance of the cell, number of parallel branches in the module and the number of cell in series in each branch.

$$
R_{s}^{M}=\frac{R_{s}^{c} \cdot N_{p}}{N_{s}}
$$

Assume that all the cell in PV system are same, so the power, voltage, and current under standard condition are

$$
\begin{gathered}
P_{\max }^{c}=\frac{P_{\text {max }}^{M}}{N_{s} \cdot N_{p}} \\
V_{o c o}^{c}=\frac{V_{o c o}^{M}}{N_{s}} \\
i_{s c o}^{c}=\frac{i_{s c o}^{M}}{N_{p}}
\end{gathered}
$$

Now the instantaneous series resistance of the PV cell can be expressed as

$$
R_{s}^{c}=\left(1-\frac{F F}{\frac{P_{m x o}^{c}}{V_{o c o}^{c} i_{x o}^{c}}}\right) \cdot \frac{V_{o c o}^{c}}{I_{s c o}^{c}}
$$

Fill factor is denoted with FF and is given as

$$
F F=\frac{\frac{V_{o c o}^{c}}{V_{T o}^{c}}-L_{n}\left(\frac{V_{o c o}^{c}}{V_{T o}^{c}}+0.72\right)}{\frac{V_{o c o}^{c}}{V_{T o}^{c}}+1}
$$

The short circuit current of the cell itself depends on the irradiance and can be expressed as

$$
i_{s c}^{c}=\frac{i_{s c o}^{c} G_{a}}{G_{a o}}
$$

The open circuit voltage of the cell depends on the nominal open circuit and the actual weather condition, i.e., ambient temperature, temperature of cell, and irradiance. The open circuit voltage is expressed $[40,41]$ as

$$
V_{o c}^{c}=V_{o c o}^{c}+0.03\left(T_{a}+0.03 \cdot G_{a}-T_{c o}\right)
$$

Now the current generated from the PV module in term of all parameters, i.e., irradiance, temperature, voltage, etc., is

$$
i^{M}=N_{p} \cdot i_{s c}^{c}\left[1-\exp \left(\frac{V^{m}-N_{s} V_{o c}^{c}+i^{m} R_{s}^{c} \frac{N_{s}}{N_{p}}}{N_{s} V_{T}^{c}}\right)\right]
$$

Now assume the case that PV array consist of $B$ number of parallel branches and each branch contain $M$ number of module so, the array current will be equal to $I=\sum_{i=1}^{N_{B}}$. If we consider all the panels are same and under same temperature and irradiance then the output current will be

$$
i_{\text {total }}=N_{B} \cdot i^{M}
$$


Table 2. List of symbols used for analytical model.

\begin{tabular}{|c|c|}
\hline Name of Parameter & Description \\
\hline$i_{\text {diode }}$ & Diode Current \\
\hline$i_{s c}$ & Short Circuit Current \\
\hline$i_{0}$ & Reserve Saturation Current \\
\hline$i_{s c}^{M}$ & Short circuit current under standard condition \\
\hline$V_{o c}^{m}$ & open voltage under standard condition \\
\hline$V_{T}$ & Thermal voltage in the semiconductor \\
\hline$P_{\max }^{c}$ & Power under standard condition \\
\hline$N_{s}$ & Cell in series in module \\
\hline$N_{p}$ & parallel branches in module \\
\hline$N_{m}$ & module in series in an array \\
\hline$N_{B}$ & parallel branches in array \\
\hline$T_{a}$ & Ambient temperature \\
\hline$T_{c}$ & Cell temperature \\
\hline$G_{a}$ & Irradiance \\
\hline K & Boltzmann Constant \\
\hline$F F$ & Fill Factor \\
\hline$D$ & Duty Cycle \\
\hline$T_{O N}$ & On time of switch \\
\hline$V_{p u}^{*}$ & Reference Voltage \\
\hline$i_{L}^{*}$ & Reference inductor current \\
\hline$m^{*}$ & Optimal duty cycle \\
\hline$L_{1,2}$ & Inductor 1 and 2 \\
\hline$C_{I N}$ & Capacitance \\
\hline$I_{L A V}$ & Inductor Average Current \\
\hline$V_{\text {OUT }}$ & Output Voltage \\
\hline
\end{tabular}

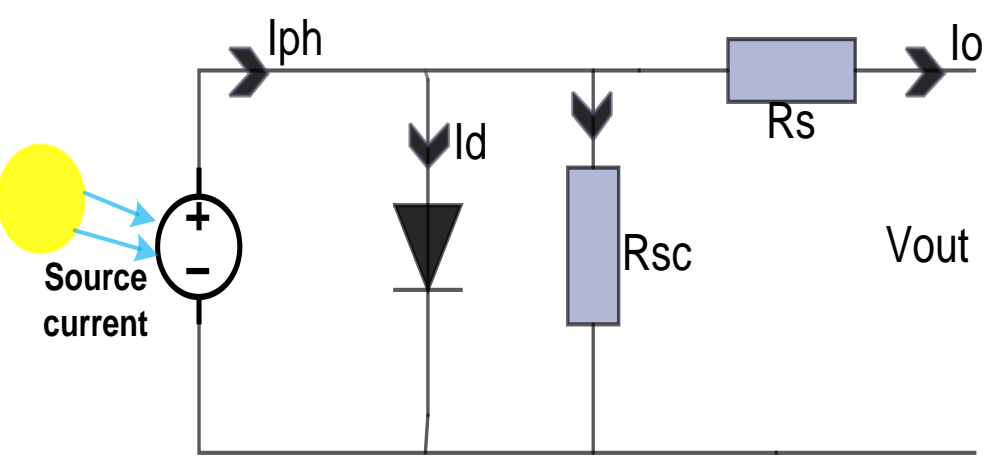

Figure 3. Equivalent circuit of photovoltaic cell.

\subsection{Analytical Modeling of a Traditional Boost Converter}

The electrical MPPT can be achieved through a DC to DC converter inserted between the photovoltaic module and the load.The DC to DC converter ensures the matching of load resistance with the varying source resistance. The converter is basically used to transfer maximum energy from source to load.

The framework of traditional boost converter is represented in Figure 4 which transfers maximum energy by adjusting the PV module output voltage to the reference voltage. The traditional boost converter has two controllable variables: Voltage $V_{p u}$ and the induc- 
tor current $i_{L}$. The mathematical model that describe the voltage and inductor current relation is

$$
\left\{\begin{array}{l}
V_{m} \\
i_{L}
\end{array}=(1-D)\left\{\begin{array}{l}
V_{m} \\
i_{L}
\end{array}\right.\right.
$$

where $D$ is the duty cycle of the boost converter, which is expressed as

$$
D=\frac{T_{o n}}{T_{\text {total }}}=T_{o n} f_{s}
$$

where $f_{s}$ is the frequency of switching of converter's switch and $T_{\text {total }}$ is the total time and $T_{O N}$ is the on time of the switch.

$$
\frac{d I_{L}}{T}=\frac{1}{L_{p u}}\left(V_{m}-V_{p u}\right)-\frac{P_{p u}}{L_{p u}}
$$

where $V_{p u}$ is the reference voltage generated by the ANN based MPPT.

$$
\frac{d V_{p u}}{d t}=\frac{\left(I_{L}-I_{p u}\right)}{P u}
$$

By using Equation (21) we obtain the reference inductor current

$$
i_{L}^{*}=\left(V_{p u}^{*}-V_{p u}\right)+I_{p u}
$$

The optimal switching voltage can be expressed by using the Equations (22) and (23)

$$
V_{m}^{*}=P I\left(V_{p u}^{*}-V_{p u}\right)+V p u+\frac{R_{p u}}{L_{p u}} I_{L}
$$

while the boost converter command is obtained by the conversion of Equation (19)

$$
D^{*}=1-\frac{V_{m}^{*}}{V_{D C}}
$$

The DC link capacitor at the output play a key role to ensure energy balance between the PV module and the power injected into the system. The DC link capacitor charge and discharge that oscillate between two levels depending on actual weather condition and power injection.

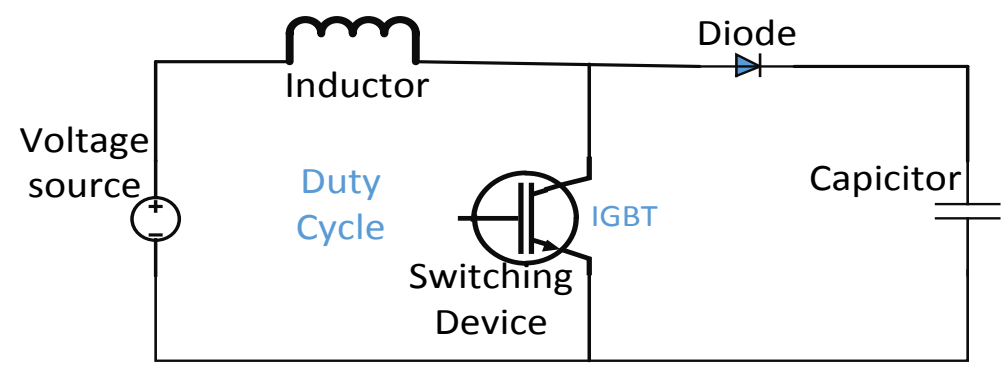

Figure 4. Traditional boost converter.

\subsection{Analytical Modelling of Enhanced Single Phase Hybrid Boost Converter}

Figure 4 shows the traditional boost converter that theoretically, voltage gain is very high at very high duty ratio near $100 \%$ but practically, traditional boost converter cannot work efficiently at $100 \%$ duty cycle because of diodes, equivalent resistance of inductor and capacitor, and the saturation of both capacitor and inductor [40,41]. In this paper, enhanced single phase $\mathrm{HBC}$ is introduced which has replaced the inductor in traditional 
boost converter into two inductors and 3 diodes, this structure provides high gain and efficiency. The gain of proposed converter is also increased than the traditional boost converter by a factor of $(d+1)$. Figure 5 shows the enhanced single phase HBC, for the mathematical modeling, we assumed that all the components are lossless and the outputs and the inputs are pure DC signals. For these consideration voltage across the inductor depends on input and output voltages. The voltage across the inductor during $\mathrm{ON}$ and OFF time are estimated as

$$
\begin{gathered}
T_{O N}: V_{L}=V_{I N} \\
T_{O F F}: V_{L}=-\frac{V_{O U T}-V_{I N}}{2}
\end{gathered}
$$

The above formula indicates that during the switch is at ON state the voltage across the inductor is positive and at OFF state voltage will be negative. The positive and negative area of the voltage of the inductor will be same. With the above condition the output voltage is calculated as

$$
V_{\text {OUT }}=\frac{1+d}{1-d} \cdot V_{I N} \text { with } \quad d=\frac{T_{O N}}{T_{P}}, 1-d=\frac{T_{O F F}}{T_{P}}
$$

The average inductor current is the function of input current from the solar module and the duty cycle of the switch

$$
I_{L A V}=\frac{I_{I N}}{1+d}
$$

To find the appropriate inductor and capacitor value in the circuit we need to know the output and input voltage of the converter and the rated power which should be transferred to the output. With these known parameters input current and average inductor current can be calculated and assumed that the average inductor current is the max current in the circuit. To find the inductor value in the circuit the input and output voltage is considered and the duty cycle is measured as

$$
\begin{gathered}
L_{1}=L_{2}=\frac{V_{I N} \cdot T_{O N}}{\triangle I_{L}} \\
L_{1}=L_{2}=\frac{V_{\text {OUT }} \cdot T_{P}}{\triangle I_{L}} \cdot \frac{d \cdot(1-d)}{1+d}
\end{gathered}
$$

The AC voltage is produced in the capacitor which overlaps with DC voltage so, because of this reason voltage variation is the key factor in capacity dimension of capacitor.

$$
\begin{gathered}
C_{I N}=\frac{I_{c} \cdot T_{O N}}{\triangle \cdot V_{c}} \\
C_{I N}=\frac{I_{L A V} \cdot T_{P}}{\triangle \cdot V_{I N \max }} \cdot d \cdot(1-d)
\end{gathered}
$$


To design the capacitor for boost converter the RMS current of the load is the important factor. Duty cycle of the average inductor current and the maximum current variation are used for the capacitor current, which are defined as

$$
I_{I N C}=I_{L A V} \sqrt{d \cdot(1-d)+\left(\frac{\triangle \cdot I_{L \max }}{I_{L A V}}\right)^{2} \cdot \frac{d^{2} \cdot(1-d)^{2} \cdot(1+3 \cdot d)}{12 \cdot(1+d)^{2}(3-2 \cdot \sqrt{2})}}
$$

The maximum voltage variation that is acceptable for the capacitor is important for the selection of output capacitor. The current time area of capacitor is the function of duty cycle and output current, which are calculated as

$$
\begin{gathered}
\text { CUUT }_{\text {OUT }}=\frac{I_{\text {OUT }} \cdot T_{P} \cdot d}{\triangle V_{\text {OUTmax }}} \\
C_{\text {OUT }}=\frac{I_{\text {LAV }} \cdot T_{P}}{\triangle V_{\text {OUTmax }}} \cdot d \cdot(1-d)
\end{gathered}
$$

Practically, acceptable voltage variation for capacitor is less than $1 \%$ of the output voltage so the output capacitor dimension is calculated is given as

$$
C_{\text {OUT }}=\frac{I_{\text {LAVR }} \cdot T_{P}}{4 \triangle V_{\text {OUTmax }}} \quad \text { with } \quad \triangle V_{\text {OUTmax }} \leq 0.01 \cdot V_{\text {out } R}
$$

The output current across the capacitor is the function of duty cycle for an average inductor current and maximum inductive current variation. So the output current will be

$$
I_{I N C}=I_{L A V} \sqrt{d \cdot(1-d)+\left(\frac{\Delta \cdot I_{L \max }}{I_{L A V}}\right)^{2} \cdot \frac{d^{2} \cdot(1-d)^{3}}{12 \cdot(1+d)^{2}(3-2 \cdot \sqrt{2})}}
$$

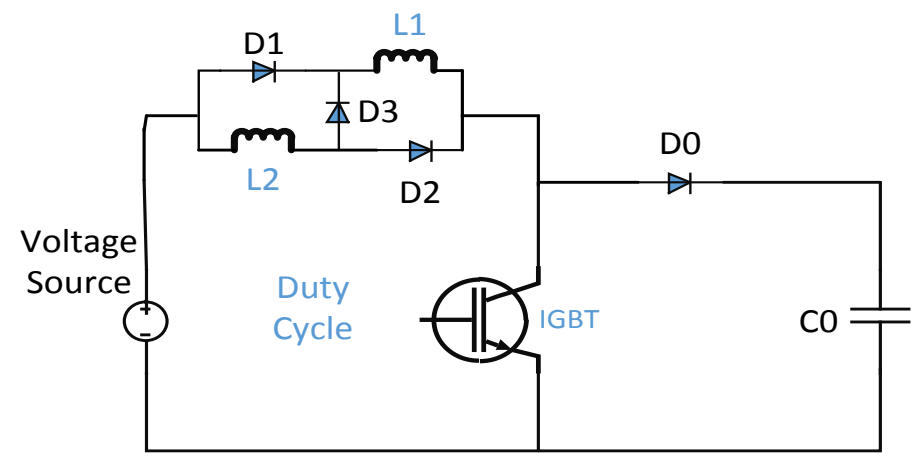

Figure 5. Enhanced single phase hybrid boost converter.

\section{Results and Discussion}

In the presented model, the ANN and HBC based MPPT is used for enhancing the productivity and performance. The results of the proposed model are compared among ANN based traditional boost converter and ANN based proposed HBC. The results of the proposed model present that the ANN based HBC MPPT give smooth output powers as compare to traditional boost converter. The proposed model is analyzed using MATLAB simulation software. The data are collected in terms of short circuit current, maximum current, open circuit voltage, maximum voltage, current temperature and voltage temperature, standard irradiance, standard temperature, maximum current of the given irradiance and temperature, maximum voltage of the given irradiance and temperature, and maximum power of the given irradiance and temperature. The temperature and irradiance are applied as input variables while the MPP voltage is used as a output of the ANN 
model. The current and power of the MPPT are estimated using V-! characteristics and multiplication of obtained current and voltage, respectively. The collected data are divided among training and testing for ANN approach. Table 3 explains the list of elements used for calculating the simulation results. Whereas the flow chart of applied algorithm is depicted in Figure 6. Figure 7 presents the correlation among tradition boost converter and proposed $\mathrm{HBC}$, which clarifies that $\mathrm{HBC}$ gain is several folds higher than traditional boost converter. Hence, with applying the proposed $\mathrm{HBC}$ the performance of ANN based MPPT is enhanced than without installed HBC MPPT system. Figure 8 shows the analysis of ANN based MPPT controller and advance hybrid converter in terms of power and time. Which declares that the irradiance level is instantly changed at $0 \mathrm{~s}, 0.04 \mathrm{~s}, 0.07 \mathrm{~s}, 0.11 \mathrm{~s}$, and $0.15 \mathrm{~s}$, and temperature is constant at $25^{\circ} \mathrm{C}$. At $0.04 \mathrm{~s}$, the range of power is constant till $0.5 \mathrm{~s}$. At $0.5 \mathrm{~s}$ the power jumped from $140 \mathrm{~W}$ to 220 where fluctuation is recorded. Similarly, this slight variations are continued in whole process as mentioned in Figure 8. Furthermore, it is depicted from Figure 8, that the ANN based MPPT has increased the smoothness of outcomes. The recorded instability in Figure 8 is highlighted in Figure 9, which shows that variation is increased from 0.0 to $0.2 \mathrm{~s}$. The constant outcomes are gained at $0.04 \mathrm{~s}$. Thus, Figure 9 defines that, in view of ANN and advance hybrid converter, the variation in generated power is optimized. The smoothness of the proposed induced power compared with conventional boost converter, which is illustrated in Figure 10 for power against time. Figure 10 clarifies that without the use of the proposed advance hybrid converter, the maximum variation in the produced power occurs. The signals achieve constant position after maximum delay. The alteration of the induced power mentioned in Figure 10 is zoomed out in Figure 11. Which explains that the fluctuations in generated power is larger than the proposed advance HBC and ANN based MPPT model. Another important term is the ripples in the output power during the constant irradiance, shown in Figure 12, which is $0.02 \mathrm{~W}$ in the proposed model. Figures 13 and 14 declare the relation among train, test, validation, and best data from the ANN approach in terms of means square error and epochs. Similarly, Figure 15 depicts the output results of the utilized AN as a function of time. The parameters like training target, training outputs, validation targets, validation outputs, test targets, test outputs, errors, and responses are evaluated in Figure 15. Figure 16a,b mention the outcomes of solar system excluding ANN and HBC based MPPT and including ANN and HBC based MPPT, respectively. In the last, the fruitful outcomes of the proposed ANN and advance hybrid boost converter based MPPT for enhancing the fidelity of the solar power system is compared with current work, as shown in Table 4.

Table 3. Parameter description used for evaluation the proposed model.

\begin{tabular}{lc}
\hline Name of Parameter & Description \\
\hline Short circuit current & $10.5 \mathrm{~A}$ \\
\hline Open circuit voltage & $22.1 \mathrm{~V}$ \\
\hline Irradiance & $700-1000 \mathrm{~W} / \mathrm{m}^{2}$ \\
\hline No of cells in module & 60 \\
\hline No of cells in series module & 8 \\
\hline No of cells in parallel & 6 \\
\hline Temperature & $25^{\circ} \mathrm{C}$ \\
\hline Maximum power & $120 \mathrm{~W}$ \\
\hline Ideal factor & 1.9 \\
\hline Maximum voltage & $620 \mathrm{v}$ \\
\hline
\end{tabular}




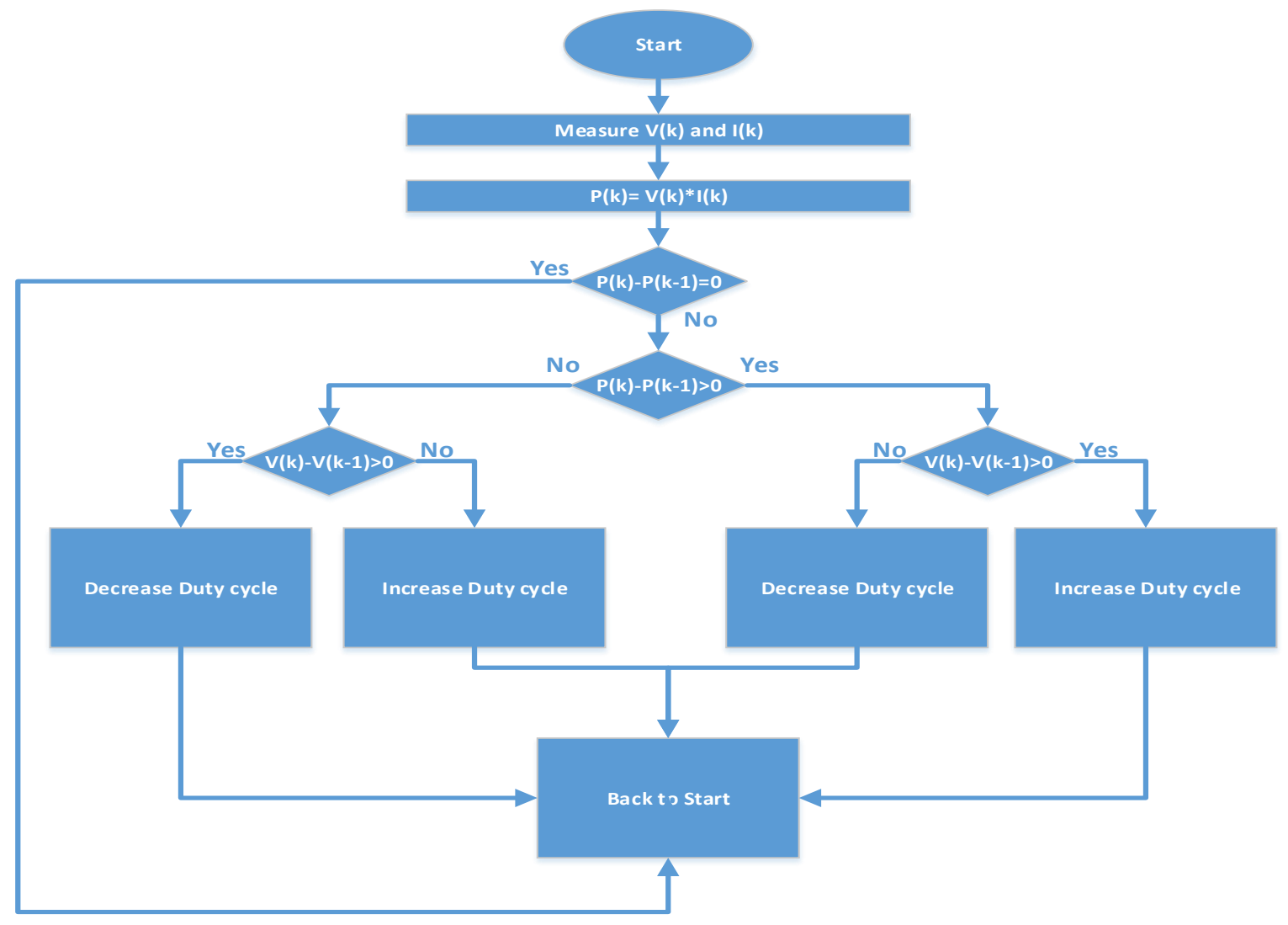

Figure 6. Flow chart description for proposed model.

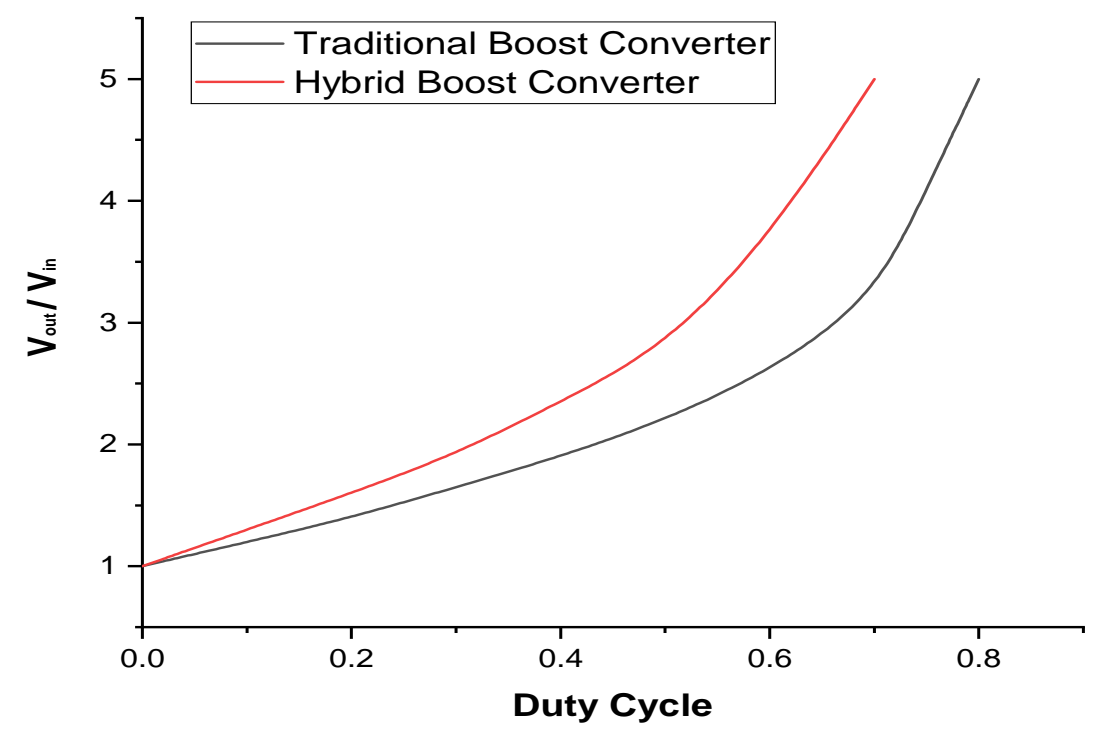

Figure 7. Comparison of traditional and hybrid boost converters in terms of voltage gain and duty cycle. 


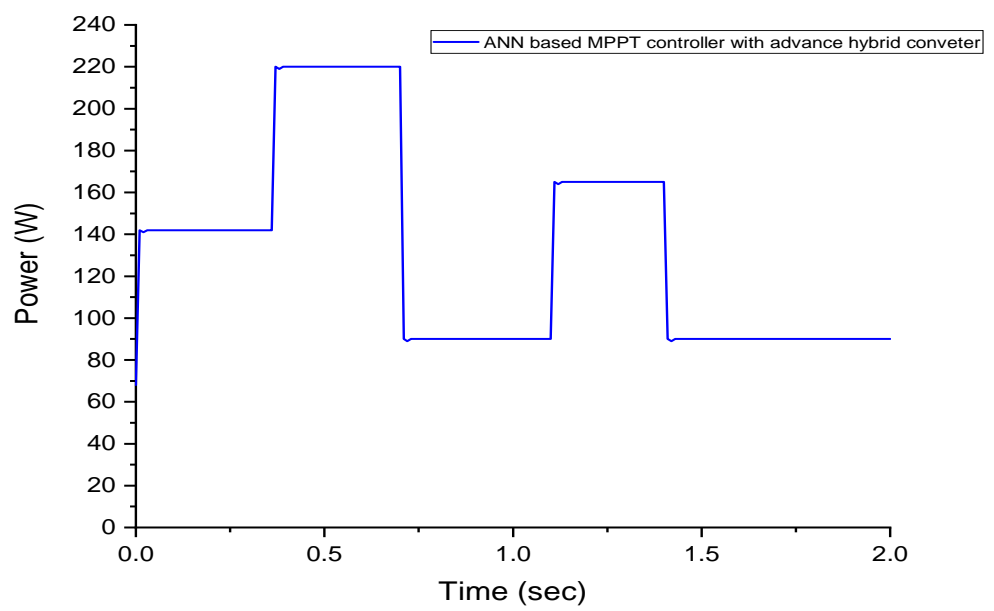

Figure 8. ANN based MPPT controller with hybrid boost converter.

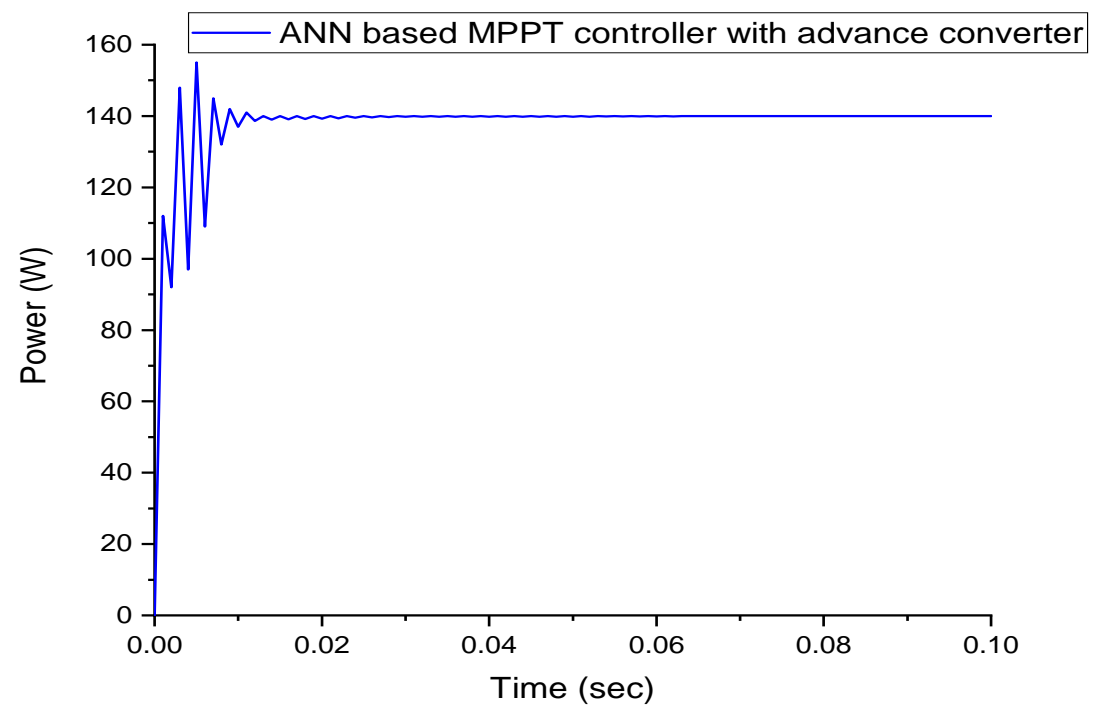

Figure 9. Zoom out portion of the ANN based MPPT controller with hybrid boost converter.

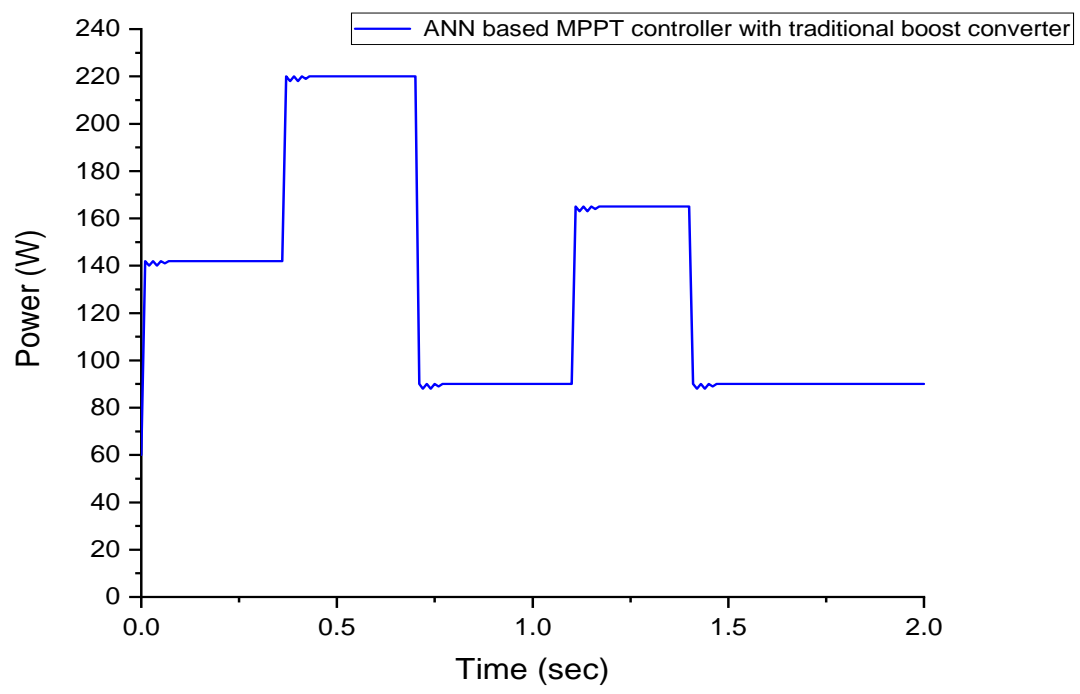

Figure 10. ANN based MPPT controller with traditional boost converter. 


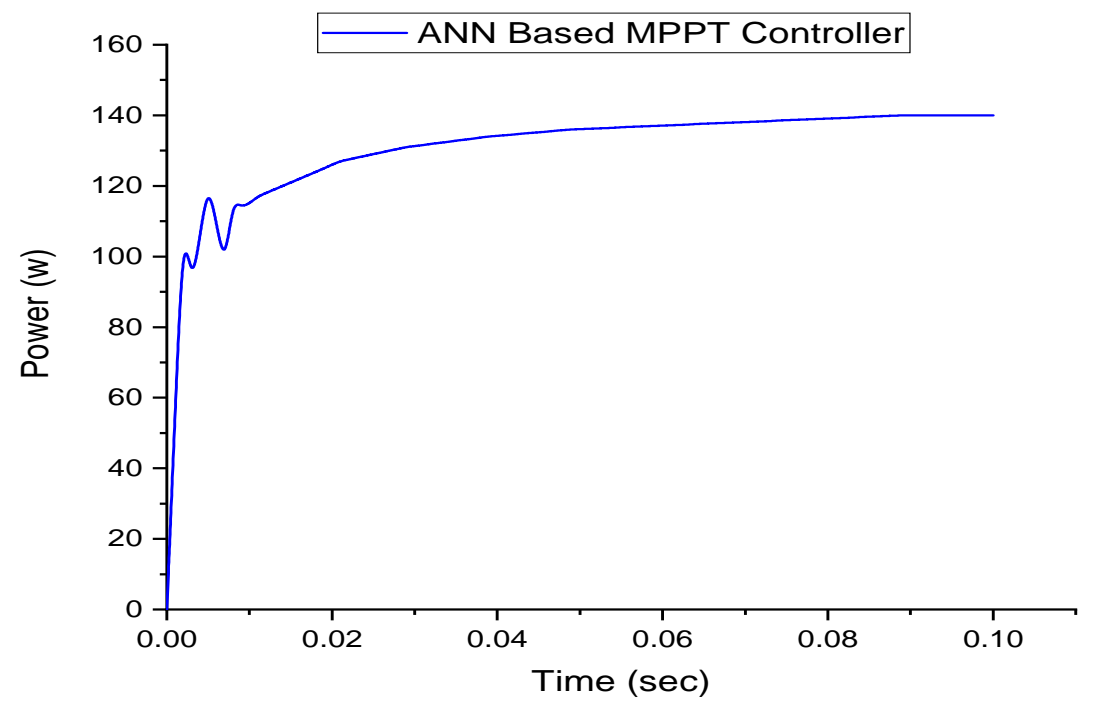

Figure 11. Analysis of varied area of the ANN based MPPT controller with traditional boost converter.

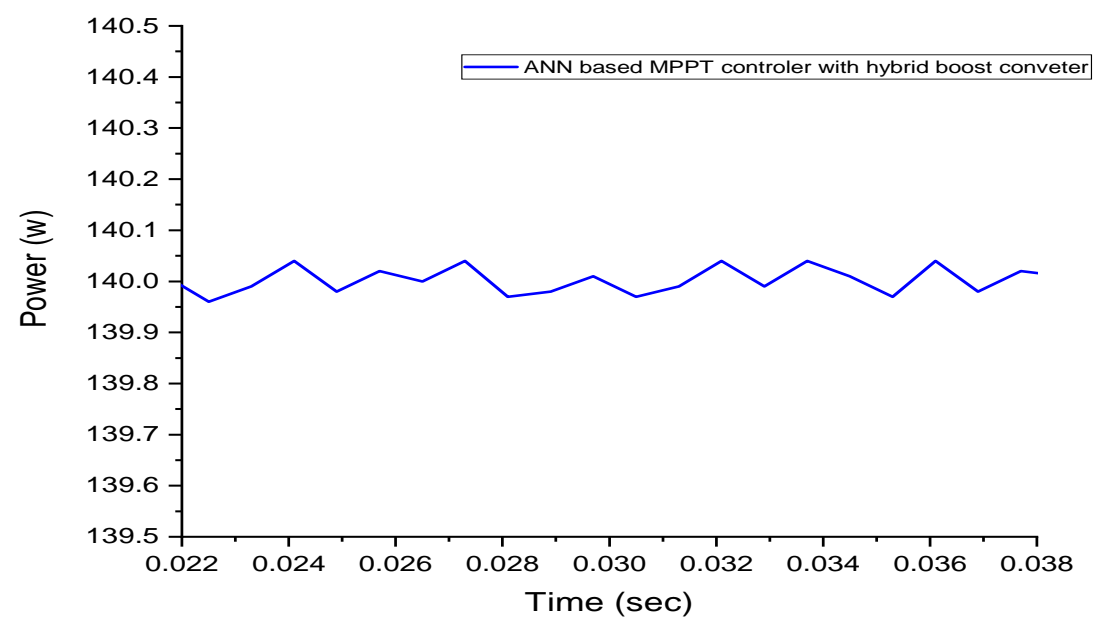

Figure 12. Power ripples of the ANN and hybrid boost converter based MPPT converter.

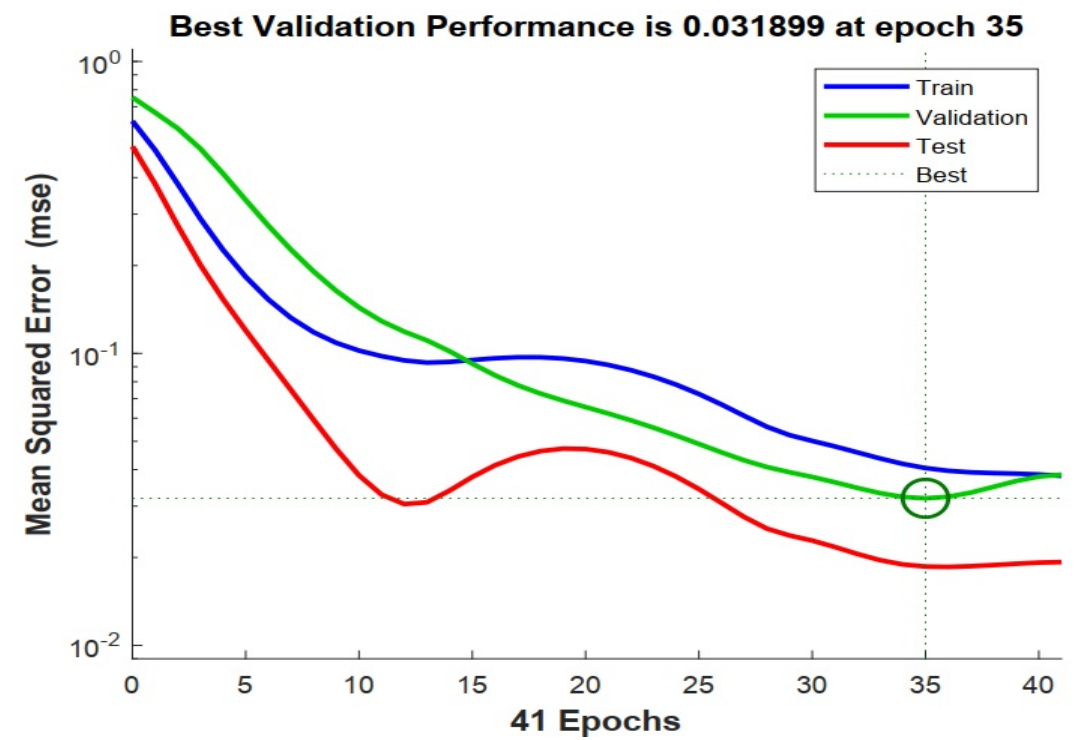

Figure 13. Maximum square error against epoch for evaluation the performance (41 Epochs). 


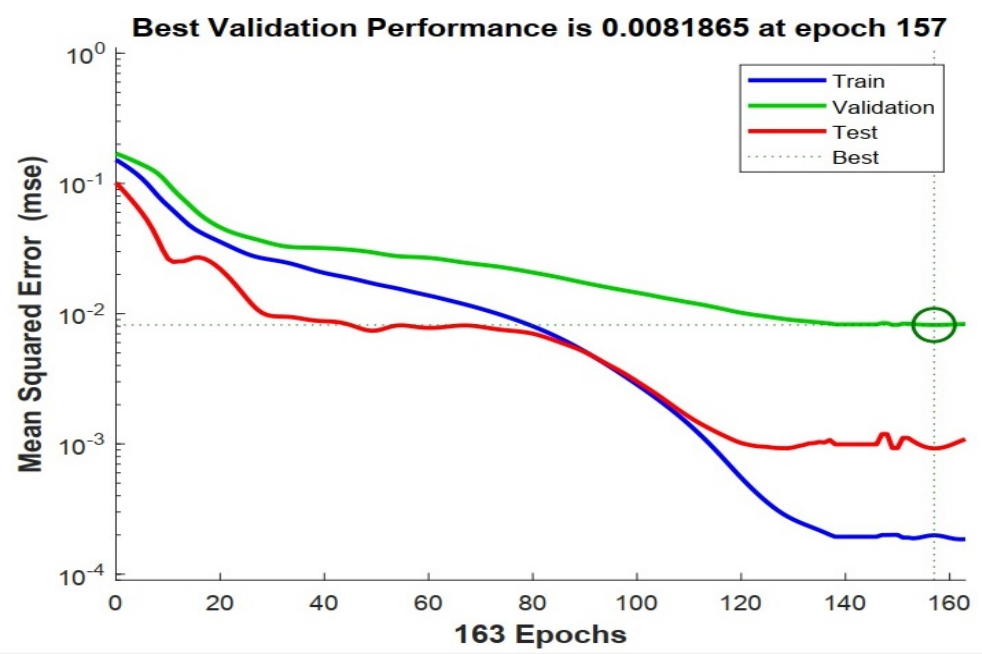

Figure 14. Maximum square error against epoch for evaluation the performance (163 Epochs).

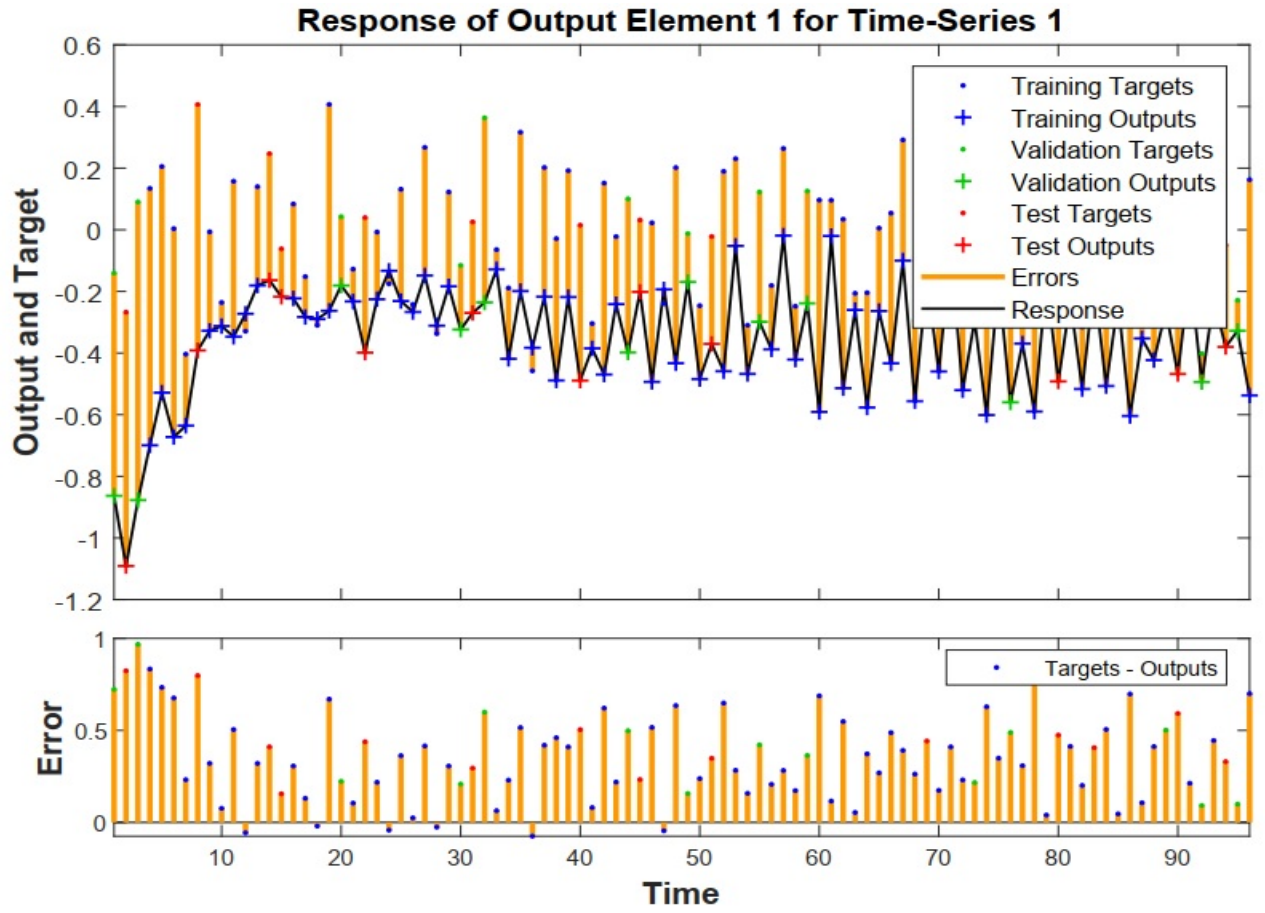

Figure 15. Measuring the output response in terms of error and output targets.

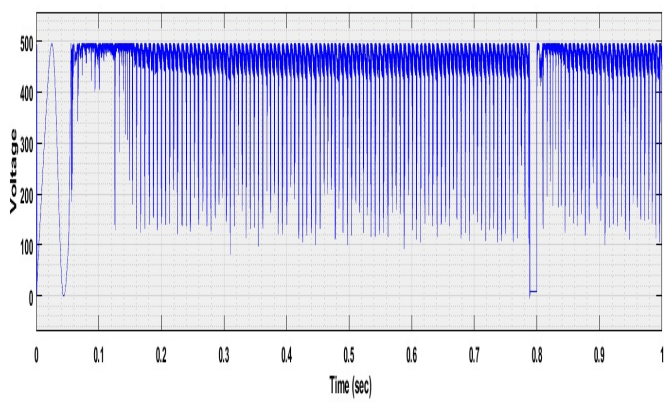

(a)

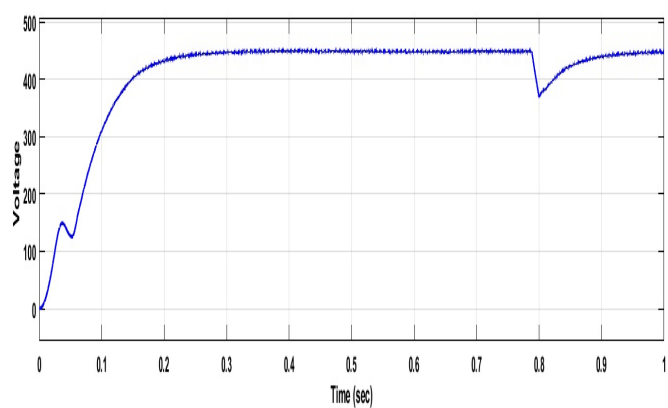

(b)

Figure 16. (a): Output results of the proposed model excluding ANN and HBC enabled MPPT, (b): Proposed model outcomes with ANN and HBC MPPT. 
Table 4. Performance comparison with current published system.

\begin{tabular}{lccc}
\hline Name of Parameter & {$[42]$} & {$[43]$} & Presented Model \\
\hline Power extraction efficiency & $68 \%$ & $80 \%$ & $85 \%$ \\
\hline Maximum error of optimum & $29 \%$ & $23 \%$ & $0.56 \%$ \\
\hline MPPT accuracy & $2.6 \%$ & $2.6 \%$ & $0.4 \%$ \\
\hline Transient response & 0.7 & 4 & 0.3 \\
\hline
\end{tabular}

\section{Conclusions}

The increase in electric load is recorded during last decade. Solar plants are the fruitful solution to minimize pressure on the main power grids. In this paper, load management is discussed using an ANN based MPPT and hybrid boost converter. Furthermore, to maintain output power smart transformer is installed before load distribution. The ANN based MPPT controller with hybrid converter have fast tracking and less fluctuations. The mechanism of ANN based is explained with mathematical background. The traditional and proposed HBC are compared theoretically and the features of HBC are highlighted. The results of proposed ANN and HBC based MPPT are evaluated in terms of power and time for using traditional boost converter with ANN and proposed HBC with ANN. The results show the superiority of solar power system with hybrid converter to improve the efficiency of solar power system. In this work, the performance and productivity of the solar power system are strengthened by utilizing the ANN and HBC based MPPT. However, in future the power generation can be further improved by using advance algorithms and machine learning methodologies, such as the flower pollination algorithm (PFA), optical swarm optimization (PSO), convolution neural network (CNN), and coyote optimization algorithm (COA). In addition, for forecasting the solar power system condition the hybrid based ANN and adaptive neural-fuzzy inference system (ANFIS) using hybrid whale optimization and pattern search (HWO-PS) algorithm can be evaluated.

Author Contributions: Conceptualization, I.H., F.A. (Farman Ali), and A.A.; methodology, F.A. (Farman Ali), and I.H.; software, F.A. (Farman Ali), and A.M., F.A. (Fayadh Alenezi); validation, F.M., F.A. (Farman Ali) and N.A.; formal analysis, F.M., F.A. (Farman Ali), A.M., F.A. (Fayadh Alemezi); investigation, A.M., F.A. (Fayadh Alenezi), A.A. and N.A. data analysis, F.A. (Farman Ali), I.H.; writing-original draft preparation, I.H.; writing—review and editing, W.K., F.A. (Fayadh Alenezi); and A.A.; visualization, F.M., F.A. (Fayadh Alenezi); supervision, F.A. (Farman Ali), A.A.; project administration, F.A. (Farman Ali); funding acquisition, W.K., N.U., F.R.A. All authors have read and agreed to the published version of the manuscript.

Funding: The authors would like to acknowledge the support from Taif University Researchers Supporting Project Number(TURSP-2020/331), Taif University, Taif, Saudi Arabia.

Institutional Review Board Statement: Not applicable

Informed Consent Statement: Not applicable

Data Availability Statement: Data will be available as per request.

Conflicts of Interest: The authors declare no conflict of interest.

\section{References}

1. Markvart, T. Solar Electricity; John Wiley \& Sons: Chichester, UK, 1994.

2. Rekioua, D.; Matagne, E. Optimization of Photovoltaic Power Systems: Modelization, Simulation and Control; Springer: London, UK, 2012.

3. De Soto, W.; Klein, S.A.; Beckman, W.A. Improvement and validation of a model for photovoltaic array performance. Sol. Energy 2006, 80, 78-88. [CrossRef]

4. Koutroulis, E.; Kalaitzakis, K.; Voulgaris, N.C. Development of a microcontroller-based, photovoltaic maximum power point tracking control system. IEEE Trans. Power Electron. 2001, 16, 46-54. [CrossRef] 
5. Sera, D.; Teodorescu, R.; Hantschel, J.; Knoll, M. Optimized maximum power point tracker for fast-changing environmental conditions. IEEE Trans. Ind. Electron. 2008, 55, 2629-2637. [CrossRef]

6. Inthamoussou, F.A.; Battista, H.D.; Mantz, R.J. New concept in maximum power tracking for the control of a photovoltaic/hydrogen system. Int. J. Hydrog. Energy 2012, 37, 14951-14958. [CrossRef]

7. Femia, N.; Petrone, G.; Spagnuolo, G.; Vitelli, M. A technique for improving P \& O MPPT performances of double-stage grid-connected photovoltaic systems. IEEE Trans. Ind. Electron. 2009, 56, 4473-4482.

8. Munir, H.K.; Nur, S.M.; Ahmed, E.-S. Wavelet based hybrid ANN-ARIMA models for meteorological drought forecasting. J. Hydrol. 2020, 590, 125380.

9. Ruiz-Aguilar, J.J.; Turias, I.; González-Enrique, J. A permutation entropy-based EMD-ANN forecasting ensemble approach for wind speed prediction. Neural Comput. Appl. 2021, 33, 2369-2391. [CrossRef]

10. Akbal, Y.; Ünlü, K.D. A deep learning approach to model daily particular matter of Ankara: Key features and forecasting. Int. J. Environ. Sci. Technol. 2021. [CrossRef]

11. Abdul, R.P.; Damhuji, R.; Kharudin, A.; Muhammad, Z.M.; Ahmed, N.A.; Moneer, A.F. Solar irradiance measurement instrumentation and power solar generation forecasting based on Artificial Neural Networks (ANN): A review of five years research trend. Sci. Total Environ. 2020, 715, 136848.

12. Esram, T.; Chapman, P.L. Comparison of photovoltaic array maximum power point tracking techniques. IEEE Trans. Energy Convers. 2007, 22, 439-449. [CrossRef]

13. Femia, G.N.; Petrone, G.; Spagnuolo, G.; Vitelli, M. Optimization of perturb and observe maximum power point tracking method. IEEE Trans. Power Electron. 2005, 20, 963-973. [CrossRef]

14. Li, G.; Wang, H.A. Novel stand-alone PV generation system based on variable step size INC MPPT and SVPWM control. In Proceedings of the IEEE 6th International Power Electronics and Motion Control Conference, IEEE-IPEMC'09, Wuhan, China, 17-20 May 2009; p. 2155e60.

15. Safari, A.; Mekhilef, S. Simulation and hardware implementation of incremental conductance MPPT with direct control method using cuk converter. IEEE Trans. Ind. Electron. 2011, 58, 1154-11561. [CrossRef]

16. Reisi, A.R.; Moradi, M.H.; Jamasb, S. Classification and comparison of maximum power point tracking techniques for photovoltaic system: A review. Renew. Sustain. Energy Rev. 2013, 19, 433-443. [CrossRef]

17. Kamarzaman, N.A.; Tan, C.W. A comprehensive review of maximum power point tracking algorithms for photovoltaic systems. Renew. Sustain. Energy Rev. 2014, 37, 585-598. [CrossRef]

18. Xiao, W.; Dunford, W.G. A modified adaptive hill climbing MPPT method for photovoltaic power systems. In Proceedings of the 35th Annual IEEE Power Electronics Specialists Conference, Aachen, Germany, 20-25 June 2004; pp. 1957-1963.

19. Liu, F.; Kang, Y.; Zhang, Y.; Duan, S. Comparison of P \& O and hill climbing MPPT methods for grid-connected PV converter. In Proceedings of the 3rd IEEE Conference on Industrial Electronics and Applications, Singapore, 3-5 June 2008; pp. 804-807.

20. Mutoh, N.; Matuo, T.; Okada, K.; Sakai, M. Prediction-databased maximum-power-pointtracking method for photovoltaic power generation systems. In Proceedings of the IEEE 33rd Annu. Power Electronics Specialists Conference, Cairns, QLD, Australia, 23-27 June 2002; pp. 1489-1494.

21. Chao, K.H.; Li, C.J.; Wang, M.H. A Maximum Power Point Tracking Method Based on Extension Neural Network for PV Systems [Part I, LNCS 5551]; Springer: Wuhan, China, 2009; pp. 745-755.

22. Yasushi, K.; Koichiro, Y.; Masahito, K. Quick Maximum Power Point Tracking of Photovoltaic Using Online Learning Neural Network. In Proceedings of the International Conference on Neural Information Processing ICONIP 2009: Neural Information Processing, Bangkok, Thailand, 1-5 December 2009; pp. 606-613.

23. Majed, B.A.; Maher, C.; Zied, C. Artificial Neural Network based control for PV/T panel to track optimum thermal and electrical power. Energy Convers. Manag. 2013, 65, 372-380.

24. Shahzad, A.; Hafiz, M.; Muhammad, A. Iftikhar, A.; Muhammad, K.A.; Zil, H.; Safdar, A.K. Supertwisting Sliding Mode Algorithm Based Nonlinear MPPT Control for a Solar PV System with Artificial Neural Networks Based Reference Generation. Energies 2020, 13, 3695. [CrossRef]

25. Liu, Y.H.; Liu, C.L.; Huang, J.W.; Chen, J.H. Neural-network-based maximum power point tracking methods for photovoltaic systems operating under fast changing environments. Sol. Energy 2013, 89, 42-53. [CrossRef]

26. Chekired, A.; Mellit, S.A.; Kalogirou, C.L. Intelligent maximum power point trackers for photovoltaic applications using FPGA chip: A comparative study. Sol. Energy 2014, 101, 83-99. [CrossRef]

27. Rajib, B.R.; Rokonuzzaman, M.; Amin, N.; Mishu, M.K.; Rahman, S.; Mithulananthan, N.; Rahman, K.S.; Shakeri, M.; Pasupuleti, J. A Comparative Performance Analysis of ANN Algorithms for MPPT Energy Harvesting in Solar PV System. IEEE Access 2021, 9, 102137-102152.

28. Fathi, M.; Parian, J.A. Intelligent MPPT for photovoltaic panels using a novel fuzzy logic and artificial neural networks based on evolutionary algorithms. Energy Rep. 2021, 7, 1338-1348. [CrossRef]

29. Jiang, M.; Ghahremani, M.; Dadfar, S.; Chi, H.; Abdallah, Y.N.; Furukawa, N. A novel combinatorial hybrid SFL-PS algorithm based neural network with perturb and observe for the MPPT controller of a hybrid PV-storage system. Control Eng. Pract. 2021, 114, 104880. [CrossRef]

30. Badreddine, B.; Amar, B.; Noureddine, H. A novel nature-inspired maximum power point tracking (MPPT) controller based on ACO-ANN algorithm for photovoltaic (PV) system fed arc welding machines. Neural Comput. Appl. 2021. [CrossRef] 
31. Zerglaine, A.; Mohammedi, A.; Bentata, K.; Rekioua, D.; Oubelaid, A.; Mebarki, N.E. Enhancement of Extracted Photovoltaic Power Using Artificial Neural Networks MPPT Controller. Adv. Green Energies Mater. Technol. 2021, 265-272._35. [CrossRef]

32. Faisal, S.; Muhammad, H.Y.; Haider, A.T.; Muhammad, R.A.; Zeeshan, A.A.; Muhammad, H.K. Performance Benchmark of Multi-Layer Neural Network Based Solar MPPT for PV Applications. In Proceedings of the 2021 International Conference on Emerging Power Technologies (ICEPT), Topi, Pakistan, 10-11 April 2021.

33. Ankit, G.; Pawan, K.; Rupendra, K.P.; Yogesh, K.C. Performance Analysis of Neural Network and Fuzzy Logic Based MPPT Techniques for Solar PV Systems. In Proceedings of the 2014 6th IEEE Power India International Conference (PIICON), Delhi, India, 5-7 December 2014.

34. Zhang, H.; Cheng, S. A new MPPT algorithm based on ANN in solar PV systems. Advances in Computer. In Communication, Control and Automation; Springer: Berlin/Heidelberg, Germany, 2011; pp. 77-84.

35. Yong, Z.; Hong, L.; Liqun, L.; Xiao, F.G. The MPPT control method by using BP neural networks in PV generating system. In Proceedings of the 2012 International Conference on Industrial Control and Electronics Engineering, Hangzhou, China, 23-25 March 2012.

36. Bendib, B.; Krim, F.; Belmili, H.; Almi1, M.F.; Bolouma, S. An Intelligent MPPT Approach based on Neural- Network Voltage Estimator and Fuzzy Controller, Applied to a Stand-alone PV System. In Proceedings of the 2014 IEEE 23rd International Symposium on Industrial Electronics (ISIE), Istanbul, Turkey, 1-4 June 2014.

37. Poom, K.; Somyot, K. Maximum Power Point Tracking Using Neural Network in Flyback MPPT inverter for PV systems. In Proceedings of the SCIS-ISIS 2012, Kobe, Japan, 20-24 November 2012.

38. Rahul, D. Neural Network MPPT Control Scheme With Hysteresis Current Controlled Inverter For Photovoltaic System. In Proceedings of the 2014 RAECS UIET Panjab University, Chandigarh, India, 6-8 March 2014.

39. Aymen, C.; Rashad, M.K.; Ken, N. A novel multi-model neuro-fuzzy-based MPPT for three-phase grid-connected photovoltaic system. Sol. Energy 2010, 84, 2219-2229.

40. Wai, R.J.; Lin, C.Y.; Duan, R.Y.; Chang, Y.R. Highefficiency dc-dc converter with high voltage gain and reduced switch stress. IEEE Trans. Ind. Electron. 2007, 54, 354-364. [CrossRef]

41. Wu, T.F.; Lai, Y.S.; Hung, J.C.; Chen, Y.M. Boost converter with coupled inductors and buck-boost type of active clamp. IEEE Trans. Ind. Electron. 2008, 55, 154-162. [CrossRef]

42. Vahedi, H.; Sharifzadeh, M.; Al-Haddad, K. Modified Seven-Level Pack U-Cell Inverter for Photovoltaic Applications. IEEE J. Emerg. Sel. Top. Power Electron. 2018, 6, 1508-1516. [CrossRef]

43. Babaie, M.; Sharifzadeh, M.; Mehrasa, M.; Chouinard, G.; AlHaddad, K. PV Panels Maximum Power Point Tracking based on ANN in Three-Phase Packed E-Cell Inverter. In Proceedings of the 2020 IEEE International Conference on Industrial Technology (ICIT), Buenos Aires, Argentina, 26-28 February 2020; pp. 854-859. [CrossRef] 